\title{
Background radiation level measurement using hand held dosimeter and gamma spectrometry in Ijebu-Ife, Ogun State Nigeria
}

\author{
P.O. Olagbaju1 ${ }^{*}$, I.C. Okeyode², O.O. Alatise ${ }^{2}$, B.S. Bada ${ }^{3}$ \\ ${ }^{1}$ Physics Department, North West University, Mafikeng Campus, South Africa \\ ${ }^{2}$ Physics Department, Federal University of Agriculture, Abeokuta. Ogun State, Nigeria \\ ${ }^{3}$ Department of Environmental Management and Toxicology, Federal University of Agriculture, Abeokuta, Ogun \\ State, Nigeria
}

\section{- Original article}

\author{
*Corresponding authors: \\ Peter O. Olagbaju, M.Sc., \\ E-mail: \\ olagbajupetero@gmail.com
}

Revised: April 2020

Accepted: June 2020

Int. J. Radiat. Res., July 2021; 19(3): $591-598$

DOI: $10.29252 /$ ijrr.19.2.591

\begin{abstract}
Background: The knowledge of distribution of radionuclides and background radiation levels in the environment is important for assessing the effects of radiation exposure due to both terrestrial and extra-terrestrial sources. Materials and Method: In-situ gamma dose survey and gamma spectrometry was employed to investigate background radiation levels in ljebu-Ife. Results: In-situ gamma dose rates vary from 0.02 to $0.10 \mu \mathrm{Sv} / \mathrm{hr}$ with mean value of $0.05 \mu \mathrm{Sv} / \mathrm{hr}$ which is less than $0.133 \mu \mathrm{Sv} / \mathrm{hr}$, recommended by the ICRP. The resulting annual effective dose was below $1 \mathrm{mSv} / \mathrm{yr}$ maximum permissible limit for the general public set by the UNSCEAR, 2000. The activity concentrations of the three naturally occurring radionuclides in soils ranged from Below Detection Level (BDL) to $320.11 \pm 28.53,9.11 \pm 1.65$ and $8.55 \pm$ $0.95 \mathrm{~Bq} / \mathrm{kg}$ with mean values of $119.05 \pm 11.24 \mathrm{~Bq} / \mathrm{kg}, 4.44 \pm 1.01 \mathrm{~Bq} / \mathrm{kg}$ and $4.55 \pm 0.62 \mathrm{~Bq} / \mathrm{kg}$ respectively which are lower than the average values of 400,35 , and $30 \mathrm{~Bq} / \mathrm{kg}$ recommended by the UNSCEAR, 2000 for ${ }^{40} \mathrm{~K},{ }^{226} \mathrm{Ra}$, and ${ }^{232} \mathrm{Th}$ respectively. The mean computed values for absorbed dose rate, annual effective dose and radium equivalent are $10.03 \mathrm{nGy} / \mathrm{hr}, 0.03 \mathrm{mSv} / \mathrm{yr}$, $20.11 \mathrm{~Bq} / \mathrm{kg}$ respectively, which fall within UNSCEAR, 2000 threshold. Conclusion: A significant positive relationship exists between the in-situ and evaluated effective dose equivalents $(r=0.89, p<0.05)$. Radiation dose results indicate insignificant radiological risk, making the study area safe for living and agriculture purposes.
\end{abstract}

Keywords: Radionuclides, in-situ dose rate, gamma spectrometry.

\section{INTRODUCTION}

Natural radioactivity is known to be naturally present in our environment (1), existing in various geological formations such as soils, rocks, plants, water and air (2), since the formation of the earth (3). Naturally occurring radionuclides are common occurrences in the environment (4) and their accumulation in air, soil, water and plant parts represents the exposure pathway to humans (1).

Human exposure from primordial sources constitutes about $85 \%$ of natural background radiation (2), making human exposure to ionizing radiation from natural sources continuous and inevitable. Background radiation serves as baseline value in assessing possible environmental radiation pollution and can also be employed in mineral characterization of an area, since environmental natural radioactivity is due to the decay of radionuclides derived from minerals presents in the earth crust (5).

Natural background radiations are mainly from rock disintegration through a natural process. They are carried to the soil by rain and flows (6), making soil radioactivity one of the main determinants of natural background radiation. Soil also plays a significant role in human exposure to Ionizing radiation $(7,8)$. Possible associations of natural background 
radiation with reported incidences of reproductive abnormalities in Abeokuta, a neighbouring town to our study area though with different geology, was observed by (9). Therefore, assessment of environmental radionuclides is of great interest to many researchers throughout the world because of the hazard it poses to the ever-growing world population (8).

Knowledge of background radiation levels in the environment is also important for assessing the effects of radiation exposure to humans, predicting the level of natural radioactivity without laboratory measurement (10), and also forms the baseline for assessment of future radioactive contamination or pollution in the environment. The aim of this study was to measure the background radiation level in Ijebu Ife, Ogun State, Nigeria, and study the relationship between in-situ measurements of gamma dose rates using portable dosimeter and laboratory measurement of soil samples.

\section{MATERIALS AND METHODS}

\section{Study area}

Ijebu-Ife in Ogun State lies within the Dahomey basin, an inland, offshore, coastal sedimentary basin in the Gulf of Guinea (11). It lies at latitude 604610011 North, 400310011 East with 67 meters' elevation above the sea level, in the tropical region of South-Western Nigeria linking the region to the eastern part of the country.

\section{Sample collection and preparation}

Samples were collected randomly from different locations in Ijebu-Ife, ranging from farm lands, river banks, around dwellings and yet to be settled areas (developing sites) as suggested by $(12,13)$ due to the lithological homogeneity of the area.

At each sampling point, a hand held survey meter and global positioning system was used to measure the absorbed dose and coordinates of the location before collecting soil samples at a depth of about $20 \mathrm{~cm}$, in order to also avoid the effect of plant cycling of the radionuclides according to (14). The collected samples were then transferred to the laboratory in a well labelled polythene bag where they were air-dried, crushed to a fine powder, sieved with a $2 \mathrm{~mm}$ mesh screen to obtain a fine-grained homogenous soil sample (15), and packed in to well labelled airtight containers in order to prevent the escape of ${ }^{220} \mathrm{Rn}$ and ${ }^{222} \mathrm{Rn}$ to bring the daughter radionuclide into secular radioactive equilibrium with their respective long-lived parents (16-18).

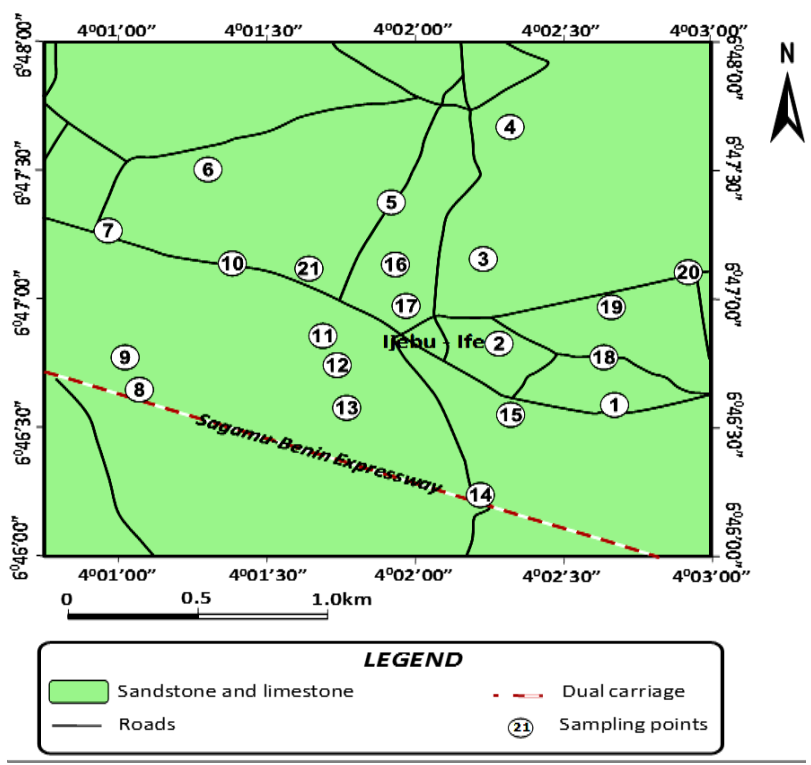

Figure 1. Geological map of the study area. Numbers in the map refers to the sampling sites in the area.

\section{Experimental Method}

In-situ absorbed dose-rate measurements using a survey meter and Gamma ray spectrometric analysis of soil samples using $\mathrm{NaI}$ (Tl) detector were employed in this study.

\section{In-situ absorbed dose rate measurements}

The survey meter is a Cesium Iodide (CsI) scintillation based Gamma RAE II $\mathrm{R}$ which provides an estimate for gamma dose rate only (10). Provided by RAE Systems P/N 047-4505000, USA), Gamma RAE II $\mathrm{R}$ is a rapid $\gamma$-ray (gamma) source detector and dosimeter in a single unit with high sensitivity to low radiation energy/level making contribution of gamma-rays from cosmic sources negligible (19). During measurements, the survey meter was held at gonad height on a tripod stand such that

Int. J. Radiat. Res., Vol. 19 No. 3, July 2021 
it is one-meter above ground level (3). At each location, absorbed dose rates $(\mu \mathrm{Sv} / \mathrm{hr})$ were measured for $5 \mathrm{~min}$ and repeated six times. The mean of the six readings over the total sampling time of 30 min was recorded according to (3) to provide desirable accuracy $(<10 \% \mathrm{SD})$ at a $95 \%$ confidence level. The mean of all the locations was computed and considered as the representative absorbed dose value for that location.

To assess the radiological implication, the annual effective doses $H_{m}\left(\frac{m s v}{y r}\right)$ corresponding to the measured gamma absorbed doses $D_{m}\left(\frac{\mu S v}{h r}\right)$, was calculated using equation 1 :

$H_{m}\left(\frac{m S v}{y r}\right)=D_{m}\left(\frac{\mu S v}{h r}\right) \times\left(24 \times 365 \frac{h r}{y r}\right) \times 0.4 \times 10^{-3}$

where 0.4 is the outdoor occupancy factor, considering that people in this area spend an average of $40 \%$ (about 10 hours) of their time outdoors.

\section{Gamma ray spectrometry}

Gamma spectrometry was done using a well shielded NaI(TI) detector from CANBERRA France of 3" x 3" crystal dimension with resolution $7.5 \%$ for $137 \mathrm{Cs}$ ( $662 \mathrm{keV}$ ) coupled to a computer-based multichannel analyzer (MCA) card system GENIE 2000 programmed used for data acquisition and spectra analysis, available at National Institute of Radiation Protection and Research (NIRPR) University of Ibadan, Nigeria with necessary energy and efficiency calibrations using IAEA standard source. Each sample was counted for 10,800 seconds and activity concentrations of ${ }^{238} \mathrm{U} /{ }^{226} \mathrm{Ra}$ and ${ }^{232} \mathrm{Th}$ were determined using the $\gamma$-lines of their decay products: ${ }^{214} \mathrm{Bi}(1764.5 \mathrm{keV})$ and ${ }^{208} \mathrm{Ti}(2614.5$ $\mathrm{keV})$, respectively while the activity concentration of ${ }^{40} \mathrm{~K}$ was determined using its $1460 \mathrm{keV} \gamma$-line.

\section{Activity concentration and radiological parameters}

The activity concentrations $\mathrm{C}\left(\mathrm{BqKg}^{-1}\right)$ of the radionuclides were calculated using equation 2 , as given by Jibiri and Okeyode (8).

$$
\mathrm{C}\left(\mathrm{BqKg}^{-1}\right)=\mathrm{KC}_{\mathrm{n}}
$$

Where; $C_{n}$ is the count rate under the corresponding peak, $K=\frac{i}{\varepsilon \rho_{y} M_{s}}$ is the efficiency of the detector at specific gamma-ray energy, $\rho_{\gamma}$ is the absolute transition probability of the specific gamma-ray, $\mathrm{M}_{\mathrm{s}}$ is the sample mass.

\section{Radium equivalent}

The radium equivalent activity $\mathrm{Ra}_{\mathrm{eq}}$ which represents the weighted sum of activities of the measured natural radionuclides and is based on the estimation that $1 \mathrm{~Bq} / \mathrm{kg}$ of ${ }^{226} \mathrm{Ra}, 0.7 \mathrm{~Bq} / \mathrm{kg}$ of ${ }^{232} \mathrm{Th}$, and $13 \mathrm{~Bq} / \mathrm{kg}$ of $40 \mathrm{~K}$ produce the same radiation dose rates, is given in equation 3 by ${ }^{8}$, 20) as:

$\mathrm{Ra}_{\mathrm{eq}}=\mathrm{C}_{\mathrm{Ra}}+1.43 \mathrm{C}_{\mathrm{Th}}+0.077 \mathrm{C}_{\mathrm{K}}$

Where; $\mathrm{C}_{\mathrm{Ra}}, \mathrm{C}_{\mathrm{Th}}$ and $\mathrm{C}_{\mathrm{K}}$ are the activity concentration in $\mathrm{Bq} / \mathrm{kg}$ of ${ }^{226} \mathrm{Ra},{ }^{232} \mathrm{Th}$, and ${ }^{40} \mathrm{~K}$.

\section{Absorbed dose rate}

The absorbed dose rate in air from terrestrial sources of gamma radiation was estimated from the result of the activity concentration of the radionuclides, using the relation given in equation 4 by Otwoma, Patel (12).

$\mathrm{D}\left(\frac{n G y}{h r}\right)=0.427 \mathrm{C}_{\mathrm{Ra}}+0.662 \mathrm{C}_{\mathrm{Th}}+0.043 \mathrm{C}_{\mathrm{K}}$

Where; $\mathrm{D}\left(\frac{n G y}{h r}\right)$ the dose rate, at $1 \mathrm{~m}$ above ground level due to ${ }^{226} \mathrm{Ra},{ }^{232} \mathrm{Th}$ and ${ }^{40} \mathrm{~K}$ in the soil samples.

\section{Annual effective dose}

The annual effective dose, $H_{E}\left(\frac{m S v}{y r}\right)$ to the population due to activity concentration of the radionuclides in soil samples was estimated using the dose conversion coefficient that converts the absorbed dose rate in air to the effective dose $\left(0.7 \frac{S v}{G y}\right)$ using equation 5 according to Sadiq and Agba (21).

$H_{E}\left(\frac{m S v}{y r}\right)=D\left(\frac{n G y}{h r}\right) \times\left(24 \times 365 \frac{h r}{y r}\right) \times 0.4 \times 0.7 \frac{S v}{G y} \times 10^{-6}$

Where; 0.4 is the outdoor occupancy factor considering that the residents spend $40 \%$ (about 10 hours) of their time outdoor on average. 


\section{External and internal hazard index}

External and internal hazard indices are used to quantify the effect of radon, a progeny of radium and its short-lived products to the respiratory organs. The External Hazard Index $\left(\mathrm{H}_{\mathrm{ex}}\right)$ is given by the equation 6:

$H_{e x}=\frac{c_{R a}}{370}+\frac{c_{T h}}{259}+\frac{c_{k}}{4810}$

The internal hazard index $\left(\mathrm{H}_{\text {in }}\right)$ is also given by equation 7 as:

$H_{i n}=\frac{C_{R a}}{185}+\frac{C_{T h}}{259}+\frac{C_{K}}{4810}$

The value of both indices must be less than unity for the radiation hazard to be negligible (2).

\section{Statistical analysis}

Statistical package for social science (SPSS) was employed for statistical analysis of data, correlation analysis was used to measure the relationship between in-situ effective dose and laboratory measured effective and represented on a scatter plot.

\section{RESULTS}

\section{In-situ absorbed dose}

One hundred and twenty-six data were obtained using a portable dose survey meter in Ijebu Ife area of Ogun state for in-situ background radiation. The average absorbed dose rate for each sampling point obtained from in-situ measurement using Gamma RAE IIR dosimeter is presented in table 1 with its corresponding effective dose estimated using equation 1. From table 1 the result of the absorbed dose rate which represents the background radiation level was found to vary from $0.02 \mu \mathrm{Sv} / \mathrm{hr}$ to $0.10 \mu \mathrm{Sv} / \mathrm{hr}$ with a mean value of $0.05 \mu \mathrm{Sv} / \mathrm{hr}$ and values of the corresponding annual effective dose ranges from $0.07 \mathrm{mSv} / \mathrm{yr}$ to $0.350 \mathrm{mSv} / \mathrm{yr}$ with a mean value of $0.182 \pm 0.02 \mathrm{mSv} / \mathrm{yr}$. The absorbed dose rate and annual effective dose result is summarized in figure 2 .
Table 1. Absorbed dose rate and annual effective dose of ljebu-Ife, Ogun State. Nigeria.

\begin{tabular}{|c|c|c|}
\hline Location Code & $\mathbf{D}_{\mathbf{m}}(\boldsymbol{\mu S v} / \mathbf{h r})$ & $\mathbf{H}_{\mathbf{m}}(\mathbf{m S v} / \mathbf{y r})$ \\
\hline S01 & 0.10 & 0.350 \\
\hline S02 & 0.04 & 0.140 \\
\hline S03 & 0.06 & 0.210 \\
\hline S04 & 0.04 & 0.140 \\
\hline S05 & 0.06 & 0.210 \\
\hline S06 & 0.07 & 0.245 \\
\hline S07 & 0.04 & 0.140 \\
\hline S08 & 0.04 & 0.140 \\
\hline S09 & 0.02 & 0.070 \\
\hline S10 & 0.09 & 0.315 \\
\hline S11 & 0.05 & 0.175 \\
\hline S12 & 0.06 & 0.210 \\
\hline S13 & 0.04 & 0.140 \\
\hline S14 & 0.06 & 0.210 \\
\hline S15 & 0.03 & 0.105 \\
\hline S16 & 0.06 & 0.210 \\
\hline S17 & 0.05 & 0.175 \\
\hline S18 & 0.03 & 0.105 \\
\hline S19 & 0.04 & 0.140 \\
\hline S20 & 0.06 & 0.210 \\
\hline S21 & 0.05 & 0.175 \\
\hline Minimum & 0.02 & 0.070 \\
\hline Maximum & 0.10 & 0.350 \\
\hline Mean \pm SD & 0.052 & $0.182 \pm 0.02$ \\
\hline & & \\
\hline & & \\
\hline
\end{tabular}

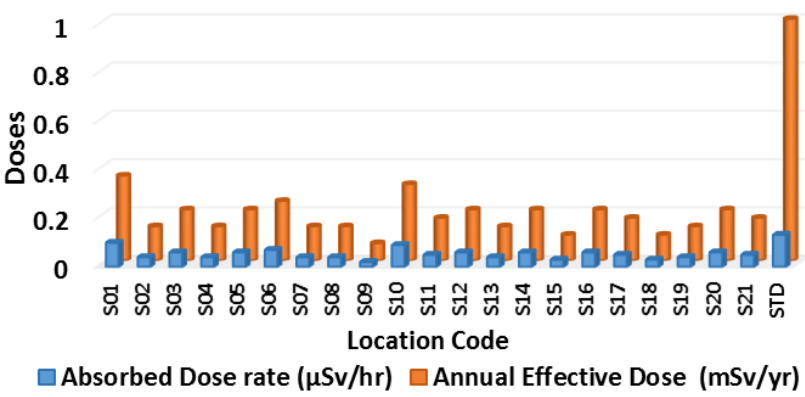

Figure 2. In-situ absorbed dose rate and annual effective dose of Ijebu-Ife, Ogun State. Nigeria and standard.

Table 2 presents the results of activity concentrations for ${ }^{226} \mathrm{Ra},{ }^{232} \mathrm{Th}$ and ${ }^{40} \mathrm{~K}$ as well as radium equivalent value in soils of Ijebu-Ife Ogun State using gamma-ray spectroscopy, while table 3 shows the values of absorbed dose rate and annual effective dose as result of human exposure because of the long-lived gamma rays in soil. From table 2, it is observed that the activity concentrations of ${ }^{40} \mathrm{~K}$ in soil varies from 
Below Detection Limits (BDL) to $320.11 \pm 28.53$ $\mathrm{Bq} / \mathrm{kg}$ with mean value of $119.052 \pm 11.24 \mathrm{~Bq} /$ $\mathrm{Kg}$, the values of the activity concentration for ${ }^{226} \mathrm{Ra}$ range from $\mathrm{BDL}$ to $9.11 \pm 1.65 \mathrm{~Bq} / \mathrm{Kg}$ with mean value of $4.444 \pm 1.01 \mathrm{~Bq} / \mathrm{Kg}$ and the values obtained for the activity concentration of ${ }^{232} \mathrm{Th}$ in soil range from BDL to $8.55 \pm 0.95 \mathrm{~Bq} / \mathrm{kg}$ with mean values of $4.545 \pm 0.62 \mathrm{~Bq} / \mathrm{Kg}$ as shown in table 2 . Table 2 also presents radium equivalent value calculated according to equation 3 , which was found to lie in the range of $6.481 \mathrm{~Bq} / \mathrm{Kg}$ to $38.186 \mathrm{~Bq} / \mathrm{kg}$ with a mean value of $20.301 \pm 1.80$.
In table 3 the absorbed dose rate of the samples was calculated using equation 4 and it was found to lie within $2.814 \mathrm{nGy} / \mathrm{hr}$ to $19.753 \mathrm{nGy} / \mathrm{hr}$ with a mean values of $10.025 \mathrm{nGy} / \mathrm{hr}$, and annual effective dose obtained using equation 5 was found to vary from $0.007 \mathrm{mSv} / \mathrm{yr}$ to $0.049 \mathrm{mSv} /$ yr with a mean value of $0.025 \mathrm{mSv} / \mathrm{yr}$. From table 3 also, external and internal radiation hazard index calculated using equation 6 and 7 was found to vary from 0.0185 to 0.1031 and 0.0297 to 0.1241 , with mean values of $0.054 \pm 0.01$ and $0.066 \pm 0.01$ respectively.

Table 2. Activity concentration of naturally occurring radionuclides and its radium.

\begin{tabular}{|c|c|c|c|c|}
\hline SAMPLE CODE & ${ }^{40} \mathbf{K}(\mathbf{B q} / \mathbf{k g})$ & ${ }^{\mathbf{2 2 6}} \mathbf{R a}(\mathbf{B q} / \mathbf{k g})$ & $\left.{ }^{\mathbf{2 3 2}} \mathbf{T h} . \mathbf{( B q} / \mathbf{k g}\right)$ & $\mathbf{R a E q}(\mathbf{B q} / \mathbf{k g})$ \\
\hline S01 & $320 \pm 28.53$ & $7.76 \pm 1.71^{`}$ & $4.04 \pm 0.48$ & 38.186 \\
\hline S02 & $30.06 \pm 2.94$ & $5.38 \pm 1.30$ & $5.61 \pm 0.61$ & 15.717 \\
\hline S03 & $148.91 \pm 14.50$ & $3.41 \pm 0.85$ & $8.55 \pm 0.95$ & 27.103 \\
\hline S04 & $120.73 \pm 11.37$ & $2.60 \pm 0.63$ & $1.14 \pm 0.14$ & 13.526 \\
\hline S05 & $253.51 \pm 21.28$ & $4.60 \pm 0.98$ & $1.26 \pm 0.16$ & 29.922 \\
\hline S06 & $249.87 \pm 22.48$ & $2.12 \pm 0.52$ & $3.42 \pm 0.42$ & 26.251 \\
\hline S07 & $125.86 \pm 11.47$ & $1.83 \pm 0.45$ & $5.95 \pm 2.72$ & 20.029 \\
\hline S08 & $68.34 \pm 7.33$ & $5.03 \pm 1.28$ & $0.59 \pm 0.08$ & 11.136 \\
\hline S09 & BDL & $5.18 \pm 1.29$ & $0.91 \pm 0.11$ & 6.481 \\
\hline S10 & $150.95 \pm 14.82$ & $8.91 \pm 1.84$ & $6.43 \pm 0.73$ & 29.728 \\
\hline S11 & $100.01 \pm 9.38$ & $3.79 \pm 0.85$ & $5.14 \pm 0.58$ & 18.841 \\
\hline S12 & $18.03 \pm 2.21$ & $4.46 \pm 1.14$ & $5.48 \pm 0.64$ & 13.685 \\
\hline S13 & $81.54 \pm 10.31$ & $9.11 \pm 1.65$ & $4.46 \pm 0.53$ & 21.766 \\
\hline S14 & $106.87 \pm 10.39$ & $8.49 \pm 1.91$ & $7.37 \pm 0.83$ & 27.258 \\
\hline S15 & $36.69 \pm 3.69$ & $3.67 \pm 0.88$ & $3.48 \pm 0.41$ & 11.472 \\
\hline S16 & $160.99 \pm 15.14$ & $4.63 \pm 0.99$ & $6.21 \pm 0.68$ & 25.907 \\
\hline S17 & $144.72 \pm 13.01$ & $1.58 \pm 0.39$ & $7.17 \pm 0.80$ & 22.977 \\
\hline S18 & $87.34 \pm 8.86$ & $2.14 \pm 0.45$ & BDL & 8.865 \\
\hline S19 & $43.15 \pm 4.43$ & BDL & $5.67 \pm 0.67$ & 11.431 \\
\hline S20 & $191.40 \pm 17.19$ & $2.64 \pm 0.68$ & $4.65 \pm 0.52$ & 24.027 \\
\hline S21 & $61.01 \pm 6.74$ & $5.99 \pm 1.44$ & $7.92 \pm 0.90$ & 22.013 \\
\hline Minimum & BDL & BDL & BDL & 6.481 \\
\hline Maximum & $320 \pm 28.53$ & $9.11 \pm 1.65$ & $8.55 \pm 0.95$ & 38.186 \\
\hline Mean $\pm S D$ & $119.05 \pm 18.19$ & $4.44 \pm 0.55$ & $4.55 \pm 0.55$ & $20.301 \pm 1.80$ \\
\hline & & & & \\
\hline
\end{tabular}


Table 3. Absorbed dose rates and annual effective dose effective dose for soils of ljebu-Ife, Ogun State.

\begin{tabular}{|c|c|c|c|c|}
\hline $\begin{array}{c}\text { SAMPLE } \\
\text { CODE }\end{array}$ & $\mathbf{D}$ (nGy/hr) & $\begin{array}{c}\mathbf{H}_{\mathrm{E}} \\
\text { (mSv/yr) }\end{array}$ & $\mathbf{H}_{\text {ex }}$ & $\mathbf{H i}_{\mathbf{n}}$ \\
\hline S01 & 19.753 & 0.048 & 0.1031 & 0.1241 \\
\hline S02 & 7.304 & 0.018 & 0.0434 & 0.0570 \\
\hline S03 & 13.519 & 0.033 & 0.0731 & 0.0824 \\
\hline S04 & 7.056 & 0.017 & 0.0365 & 0.0436 \\
\hline S05 & 13.699 & 0.034 & 0.0700 & 0.0824 \\
\hline S06 & 13.914 & 0.034 & 0.0719 & 0.0766 \\
\hline S07 & 10.132 & 0.025 & 0.0541 & 0.0590 \\
\hline S08 & 5.477 & 0.013 & 0.0301 & 0.0437 \\
\hline S09 & 2.814 & 0.007 & 0.0185 & 0.0315 \\
\hline S10 & 14.552 & 0.036 & 0.0803 & 0.1044 \\
\hline S11 & 9.321 & 0.023 & 0.0519 & 0.0611 \\
\hline S12 & 6.307 & 0.016 & 0.0370 & 0.0490 \\
\hline S13 & 10.349 & 0.025 & 0.0598 & 0.0834 \\
\hline S14 & 13.010 & 0.032 & 0.0746 & 0.0966 \\
\hline S15 & 5.449 & 0.013 & 0.0310 & 0.0409 \\
\hline S16 & 13.011 & 0.032 & 0.0710 & 0.0825 \\
\hline S17 & 11.644 & 0.029 & 0.0620 & 0.0663 \\
\hline S18 & 4.669 & 0.011 & 0.0249 & 0.0297 \\
\hline S19 & 5.609 & 0.014 & 0.0319 & 0.0309 \\
\hline S20 & 12.436 & 0.031 & 0.0659 & 0.0720 \\
\hline S21 & 10.424 & 0.026 & 0.0595 & 0.0756 \\
\hline Minimum & 2.814 & 0.007 & 0.0249 & 0.0297 \\
\hline Maximum & 19.753 & 0.048 & 0.1031 & 0.1241 \\
\hline Mean & $10.021 \pm$ & $0.025 \pm$ & $0.054 \pm$ & $0.066 \pm$ \\
\pm SD & 0.92 & 0.00 & 0.01 & 0.01 \\
\hline & & & & \\
\hline
\end{tabular}

In-situ and laboratory measured effective dose

Table 4 presents the results of in-situ and laboratory measured effective doses with in-situ effective dose ranging from $0.070 \mathrm{mSv} / \mathrm{yr}$ to $0.350 \mathrm{mSv} / \mathrm{yr}$, with a mean value $0.182 \pm 0.02$ $\mathrm{mSv} / \mathrm{yr}$ while effective dose result obtained from laboratory measurement of activity concentration of soil samples ranged from 0.007 $\mathrm{mSv} / \mathrm{yr}$ to $0.048 \mathrm{mSv} / \mathrm{yr}$ with mean values of $0.025 \mathrm{mSv} / \mathrm{yr}$. The relationship between in-situ and laboratory measurement of effective dose is presented in figure 3 , which shows a linear relationship between in-situ and laboratory measured effective dose. The correlation coefficient ( $\mathrm{r}=0.89, \mathrm{p}<0.05)$, also shows a significant positive relationship between in-situ and laboratory measured effective dose in figure 3 .
Table 4. In-situ and Laboratory measured effective dose of ljebu-Ife, Ogun State.

\begin{tabular}{|c|c|c|}
\hline Location Code & $\mathbf{H}_{\mathrm{E}}(\mathbf{m S v} / \mathbf{y r})$ & $\mathbf{H}_{\mathbf{m}}$ ( $\left.\mathbf{m S v} / \mathbf{y r}\right)$ \\
\hline S01 & 0.048 & 0.350 \\
\hline S02 & 0.018 & 0.140 \\
\hline S03 & 0.033 & 0.210 \\
\hline S04 & 0.017 & 0.140 \\
\hline S05 & 0.034 & 0.210 \\
\hline S06 & 0.034 & 0.245 \\
\hline S07 & 0.025 & 0.140 \\
\hline S08 & 0.013 & 0.140 \\
\hline S09 & 0.007 & 0.070 \\
\hline S10 & 0.036 & 0.315 \\
\hline S11 & 0.023 & 0.175 \\
\hline S12 & 0.016 & 0.210 \\
\hline S13 & 0.025 & 0.140 \\
\hline S14 & 0.032 & 0.210 \\
\hline S15 & 0.013 & 0.105 \\
\hline S16 & 0.032 & 0.210 \\
\hline S17 & 0.029 & 0.175 \\
\hline S18 & 0.011 & 0.105 \\
\hline S19 & 0.014 & 0.140 \\
\hline S20 & 0.031 & 0.210 \\
\hline S21 & 0.026 & 0.175 \\
\hline Minimum & 0.007 & 0.070 \\
\hline Maximum & 0.048 & 0.350 \\
\hline Mean \pm SD & $0.025 \pm 0.00$ & $0.182 \pm 0.02$ \\
\hline & & \\
\hline & & 0.030 \\
\hline
\end{tabular}

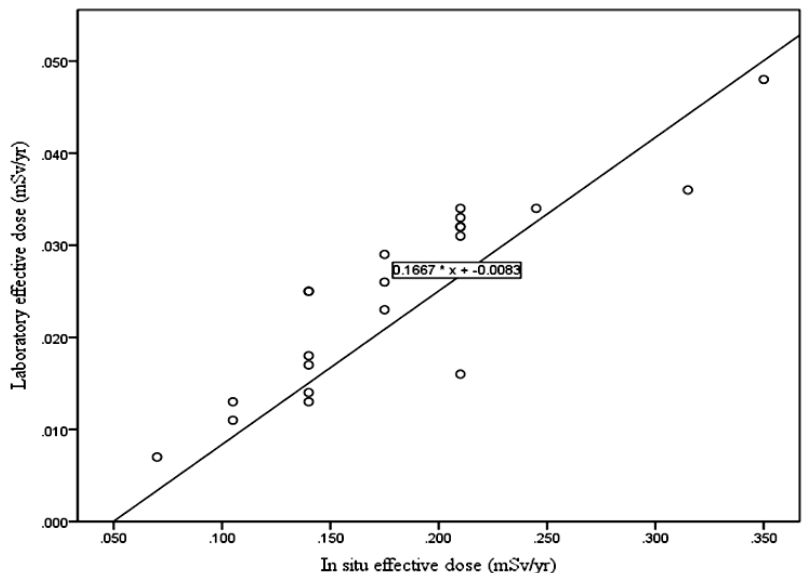

Figure 3. Correlation between in-situ effective dose and laboratory effective dose.

\section{DISCUSSION}

Generally, the gamma absorbed dose rate recorded in all locations using a hand held survey meter are within the same range, which 
can be attributed to geological homogeneity of the study area (11). Absorbed dose rates for all measured locations fall below the standard background radiation level of $0.133 \mu \mathrm{Sv} / \mathrm{hr}$, recommended by the International Commission on Radiological Protection (22) and the corresponding effective dose was below the 1 $\mathrm{mSv} / \mathrm{yr}$ maximum permissible limit for the general public set by the United Nations for Scientific Committee on the Effects of Atomic Radiation (3), and $2.3 \mathrm{mSv} / \mathrm{yr}$ in India (10,23), 0.19-1.64 mSv/yr in Abeokuta Nigeria (24). The low radiation levels in the area can be attributed to natural sources as there is no contribution from artificial sources or cosmic radiation (19).

The high-level activity concentration of potassium-40 compared to thorium- 232 and radium-226 could be due to the presence of sandstone, known to host the mineral feldspar (potassium) as the second most abundant mineral in the study area and as a result of the abundance of ${ }^{40} \mathrm{~K}$ in nature. The low levels of thorium and radium are also associated with the absence of black sands, which are enriched in the mineral monazite (25). The values obtained for the activity concentration of ${ }^{40} \mathrm{~K},{ }^{226} \mathrm{Ra}$, and ${ }^{232} \mathrm{Th}$ are lower than the world's average value of 400,30 , and $35 \mathrm{BqKg}^{-1}$ for ${ }^{40} \mathrm{~K},{ }^{226} \mathrm{Ra}$, and ${ }^{232} \mathrm{Th}$, respectively reported by (2) and values obtained in other part of the country $(8,16)$. Radiological parameters such as radium equivalent activity, absorbed dose rate, effective dose, external and internal hazard index, have their mean values $20.11 \mathrm{~Bq} / \mathrm{Kg}, 10.025 \mathrm{nGy} / \mathrm{hr}$ and $0.025 \mathrm{mSv} / \mathrm{yr}$, below the recommended limit of $370 \mathrm{~Bq} / \mathrm{Kg}, 60 \mathrm{nGy} / \mathrm{hr}$ and $1 \mathrm{mSv} / \mathrm{yr}$ and unity respectively (2). The low radiological hazard indices imply there is no radiation exposure threat in the study area and the soil is safe for building and agricultural purposes, which is the principal occupation of its residents. The low radioactivity level is attributed to the presence of sandstone and limestone, which form the underlying soil, and the absence of clay minerals (25) in the study area, and the low variation in the soil radioactivity is attributed to the lithological homogeneity of the study area as observed from the geological map in figure 1.

Int. J. Radiat. Res., Vol. 19 No. 3, July 2021
The in-situ effective dose measured using a survey meter was found to be higher than the calculated effective dose rate from the measured activity concentrations of naturally occurring radionuclides in the laboratory, because of on field contributions and the difference in sampling techniques and sampling (26). Correlation analysis shows a linear relationship between effective dose rate values measured using the survey meter, and activity concentration of soil indicates a significant positive correlation $\left(R^{2}=0.89\right)$ between the results of the two different methods, which is in accordance with the observations of (27), for low dose values. Thus, high effective dose rates from measured activity concentration of naturally occurring radionuclides are associated with a higher in-situ dose rate measured using a survey meter.

\section{CONCLUSION}

In-situ measurements of the gamma absorbed dose rates using a survey meter and analysis of the soil samples from Ijebu-Ife, Ogun State, revealed background radiation levels to be as low as reasonably achievable for members of the general public, and the estimated radiological parameters were found to be below the threshold values recommended by the United Nations Scientific Committee on the Effects of Atomic Radiation (2). The low background radiation level compared to the world average values of $1 \mathrm{mSv} / \mathrm{yr}$ (2) and those obtained from other places is attributed to the type of geology and underlying rock/soils present in the study area (25). Hence, the results obtained will form the baseline data for assessing the contribution to radiation in the environment from future industrial activities in Ijebu-Ife.

\section{Conflicts of interest: Declared none.}

\section{REFERENCES}

1. Ibikunle SB, Arogunjo AM, Ajayi OS (2019) Characterization of radiation dose and soil-to-plant transfer factor of 


\section{Olagbaju et al. / Background radiation in ljebu-Ife, Ogun State, Nigeria}

natural radionuclides in some cities from south-western Nigeria and its effect on man. Scientific African, 3: e00062.

2. United Nations Scientific Committee on the Effects of Atomic Radiation (2000) Sources and effects of ionizing radiation: sources: United Nations Publications.

3. Okeyode I, Oladotun I, Alatise O, Bada B, Makinde V, Akinboro $F(2019)$ Indoor gamma dose rates in the high background radiation area of Abeokuta, South Western Nigeria. Journal of Radiation Research and Applied Sciences, 12(1): 72-7.

4. Masok F, Masiteng $P$, Mavunda R, Maleka $P$, Winkler $H$ (2018) Measurement of radioactivity concentration in soil samples around phosphate rock storage facility in Richards Bay, South Africa. J Radiat Res App Sci, 11(1): 29-36.

5. Guagliardi I, Ricca N, Cipriani MG, Civitelli D, Froio R, Gabriele A, (2011) Natural radioactivity distribution and soil properties: a case study in Southern Italy. Spatial2 Conference: Spatial Data Methods for Environmental and Ecological Processes, Foggia (IT), 1-2 September 2011 Università degli studi di Bergamo.

6. Taskin H, Karavus M, Ay P, Topuzoglu A, Hidiroglu S, Karahan $G$ (2009) Radionuclide concentrations in soil and lifetime cancer risk due to gamma radioactivity in Kirklareli, Turkey. Journal of Environmental Radioactivity, 100(1): 4953.

7. Mathuthu M, Dlamini SG, Njinga RL (2018) Exposure risks assessment due to gamma emitting radionuclides in soils and consumable waters around princess gold mine dump in Roodepoort, South Africa. Mine Water and the Environment, 37(1): 98-105.

8. Jibiri N and Okeyode I (2011) Activity concentrations of natural radionuclides in the sediments of Ogun River, Southwestern Nigeria. Radiation Protection Dosimetry, 147(4): 555-64.

9. Jibiri NN and Famodimu JB (2013) Natural background radiation dose rate levels and incidences of reproductive abnormalities in high radiation area in Abeokuta, Southwestern Nigeria. Natural Sciencem, 5(11): 1145.

10. Al-Azmi D (2013) Performance of some handheld dosimeters used for gamma-ray ambient dose rate measurements. International Journal of Low Radiation, 9(2): 95109.

11. Ikhane P, Omosanya K, Akinmosin A, Odugbesan A (2012) Electrical resistivity imaging(ERI) of slope deposits and structures in some parts of Eastern Dahomey Basin. Journal of Applied Sciences(Faisalabad), 12(8): 716-26.

12. Otwoma D, Patel J, Bartilol S, Mustapha A (2012) Radioactivity and dose assessment of rock and soil samples from Homa Mountain, Homa Bay County, Kenya.

13. Navas Izquierdo A, Gaspar Ferrer L, López-Vicente $M$, López-Vicente M, Machín Gayarre J (2011) Spatial distribution of natural and artificial radionuclides at the catchment scale (South Central Pyrenees).
14. O'Dea J and Dowdall M (1999) Spatial analysis of natural radionuclides in peat overlying a lithological contact in Co. Donegal, Ireland. Journal of Environmental Radioactivity, 44(1): 107-17.

15. International Atomic Energy Agency (1989) IAEA bulletin: Division of Public Information; Information IAEADoP

16. Gbadebo A (2011) Natural radionuclides distribution in the granitic rocks and soils of abandoned quarry sites, Abeokuta, Southwestern Nigeria. Asian Journal of Applied Sciences, 4(2): 176-85.

17. Suresh G, Sutharsan P, Ramasamy V, Venkatachalapathy $R$ (2012) Assessment of spatial distribution and potential ecological risk of the heavy metals in relation to granulometric contents of Veeranam lake sediments, India. Ecotoxicology and Environmental Safety, 84: 117-24.

18. Bello IA, Jibiri N, Momoh H (2014) Determination of external and internal hazard indices from naturally occurring radionuclide in rock, sediment and building samples collected from Sikiti, Southwestern Nigeria. J Nat Sci Res, 4 (12): 74-81.

19. Ramli AT, Hussein AWM, Lee M (2001) Geological influence on terrestrial gamma radiation dose rate in the Malaysian State of Johore. Applied Radiation and Isotopes, $\mathbf{5 4}$ (2): 327-33.

20. Avwiri G, Osimobi J, Agbalagba E (2013) Natural occurring radionuclide variation with a soil depth profile of Udi and Ezeagu local government areas of Enugu State, Nigeria. Facta universitatis-series: Working and Living Enviromental Protection, 10(1): 53-60.

21. Sadiq A and Agba E (2011) Background radiation in Akwanga, Nigeria. Facta universitatis-series: Working and Living Enviromental Protection, 8(1): 7-11.

22. James I, Moses I, Vandi J, Ikoh U (2015) Measurement of indoor and outdoor background ionising radiation levels of Kwali General Hospital, Abuja. Journal of Applied Sciences and Environmental Management, 19(1): 89-93.

23. Ramachandran T (2011) Background radiation, people and the environment.

24. Farai I and Vincent $U$ (2006) Out-door radiation level measurement in Abeokuta, Nigeria, by thermoluminescent dosimetry. Nigerian Journal of Physics, 18(1): 121-6.

25. Ramasamy V, Senthil S, Meenakshisundaram V (2009) Distribution of natural radionuclides and minerals in beach sediments from north east coast of Tamilnadu, India. African Journal of Basic and Applied Sciences, 1(1-2):15-20.

26. Adewale O, Tubosun I, Ojo J (2015) Assessment of terrestrial naturally occurring radioactive material in soil and mine tailings of Awo and Ede, Osun-State, Nigeria. Ife Journal of Science, 17(1): 199-209.

27. Monica S, Prasad AV, Soniya S, Jojo P (2019) Comparison of gamma dose levels in assessed by various methods. Materials Today: Proceedings, 16:776-83. 